OPEN ACCESS

Edited by:

Maria Pia Cicalese, San Raffaele Scientific Institute

(IRCCS), Italy

Reviewed by:

Constantinos Petrovas, National Institutes of Health (NIH),

United States

Thomas Ciucci,

National Cancer Institute (NCl),

United States

*Correspondence:

Deepak A. Rao

darao@bwh.harvard.edu

Specialty section:

This article was submitted to

$T$ Cell Biology,

a section of the journal

Frontiers in Immunology

Received: 30 May 2018 Accepted: 06 August 2018 Published: 23 August 2018

Citation:

Rao DA (2018) T Cells That Help B Cells in Chronically Inflamed Tissues.

Front. Immunol. 9:1924.

doi: 10.3389/fimmu.2018.01924

\section{T Cells That Help B Cells in Chronically Inflamed Tissues}

\author{
Deepak A. Rao*
}

Division of Rheumatology, Immunology, Allergy, Department of Medicine, Brigham and Women's Hospital, Harvard Medical School, Boston, MA, United States

Chronically inflamed tissues commonly accrue lymphocyte aggregates that facilitate local T cell-B cell interactions. These aggregates can range from small, loosely arranged lymphocyte clusters to large, organized ectopic lymphoid structures. In some cases, ectopic lymphoid structures develop germinal centers that house prototypical $T$ follicular helper (Tfh) cells with high expression of Bcl6, CXCR5, PD-1, and ICOS. However, in many chronically inflamed tissues, the $T$ cells that interact with $B$ cells show substantial differences from Tfh cells in their surface phenotypes, migratory capacity, and transcriptional regulation. This review discusses observations from multiple diseases and models in which tissue-infiltrating $T$ cells produce factors associated with B cell help, including IL-21 and the B cell chemoattractant CXCL13, yet vary dramatically in their resemblance to Tfh cells. Particular attention is given to the PD- $1^{\text {hi }}$ CXCR5 ${ }^{-}$Bcl $6^{\text {low }} \mathrm{T}$ peripheral helper (Tph) cell population in rheumatoid arthritis, which infiltrates inflamed synovium through expression of chemokine receptors such as CCR2 and augments synovial B cell responses via CXCL13 and IL-21. The factors that regulate CD4 ${ }^{+} \mathrm{T}$ cell production of CXCL13 and IL-21 in these settings are also discussed. Understanding the range of $\mathrm{T}$ cell populations that can provide help to $\mathrm{B}$ cells within chronically inflamed tissues is essential to recognize these cells in diverse inflammatory conditions and to optimize either broad or selective therapeutic targeting of B cell-helper T cells.

Keywords: T follicular helper cells, T peripheral helper cells, IL-21, CXCL13, B cells, ectopic lymphoid structure, ectopic lymphoid follicle, tertiary lymphoid tissue

\section{INTRODUCTION}

$\mathrm{CD}^{+} \mathrm{T}$ cells play a critical role in stimulating effective $\mathrm{B}$ cell responses and production of highaffinity antibodies. $\mathrm{T}$ follicular helper (Tfh) cells are generally considered the dominant $\mathrm{T}$ cell population capable of providing help to B cells. The interactions between Tfh cells and B cells within follicles of secondary lymphoid organs (SLOs) occur with precise spatial and temporal coordination to yield productive antibody responses. Yet in both protective and pathologic immune responses, T cell-B cell interactions also occur outside of SLOs and within inflamed peripheral tissues. Interactions between $\mathrm{T}$ cells and $\mathrm{B}$ cells within peripheral tissues are much less well characterized, and the $\mathrm{T}$ cell populations that participate in these interactions can differ from Tfh cells in their surface features, migration patterns, and effector functions. This review examines the phenotypes of $\mathrm{T}$ cells within peripheral tissues that express factors associated with providing $\mathrm{B}$ cell help, in particular IL-21 and CXCL13. In many cases, the T cells that help B cells within peripheral tissues do not conform to the typical phenotype of active Tfh cells and often lack the signature features of Tfh cells such as high expression of CXCR5 and Bcl6. These observations underscore 
that a broader definition of $\mathrm{B}$ cell-helper $\mathrm{T}$ cells is required to fully capture the range of $\mathrm{T}$ cells capable of productive $\mathrm{T}$ cell- $\mathrm{B}$ cell interactions, in particular during pathologic chronic immune responses.

\section{THE T FOLLICULAR HELPER PARADIGM}

The discovery and characterization of Tfh cells has helped define the paradigm of productive $\mathrm{T}$ cell- $\mathrm{B}$ cell interactions and has established Tfh cells as the prototype of a B cell-helper T cell (1). Tfh cells are drawn into lymphoid follicles through expression of CXCR5, a chemokine receptor shared with $\mathrm{B}$ cells that detects the chemokine CXCL13 (2-4). Expression of CXCR5 is a defining feature of Tfh cells, a logical association given that this chemokine receptor helps direct these cells to the location after which they are named (5-8). The transcription factor Ascl2 enables early CXCR5 expression, which is then reinforced by the central Tfh transcription factor Bcl6 (9-13). Upregulation of CXCR5 and downregulation of CCR7 induces migration of CXCR5 ${ }^{+} \mathrm{T}$ cells into follicles, where interactions with B cells enhance Bcl6 expression and stabilize the Tfh cell phenotype, in part through ICOS-ICOSL interactions (10, 14-16).

Bcl6 is essential for the development and persistence of Tfh cells in vivo and promotes expression of many Tfh cell-associated factors, including CXCR5, ICOS, PD-1, and CXCL13, while suppressing alternative differentiation paths $(10-13,17)$. Human but not mouse Tfh cells produce large amounts of CXCL13, which helps to recruit CXCR5 ${ }^{+}$B cells to follicles $(13,18,19)$. In addition, Tfh cells characteristically express IL-21, a cytokine that promotes $\mathrm{B}$ cell proliferation in germinal centers (GC) and differentiation into plasma cells (20-22). While there is heterogeneity in Tfh cell phenotypes and functions in SLOs, GC-Tfh display the most pronounced B cell-helper phenotype, with high expression of CXCR5, Bcl6, CXCL13, and IL-21 accompanied by high expression of the immunomodulatory receptors ICOS and PD-1 $(1,18,20,23)$. These 4 key features of GC-Tfh cells: (1) CXCR5 expression, (2) high Bcl6 expression, (3) surface expression of PD-1 and ICOS, and (4) secretion of IL-21 and CXCL13, are commonly assayed in studies looking for Tfhlike cells at sites outside of SLOs, including blood and peripheral tissues.

\section{T CELL-B CELL INTERACTIONS IN INFLAMED TISSUES}

During an adaptive immune response, activated $\mathrm{T}$ cells differentiate into distinct effector populations that acquire specialized functions coupled with appropriate migratory programs. For example, activated effector or effector memory cells home to peripheral tissues to direct inflammatory responses, while CXCR5 ${ }^{+}$Tfh cells migrate to lymphoid follicles to help B cells (24). Migratory capacity sometimes serves as a defining feature of $\mathrm{T}$ cell populations: $\mathrm{CCR}^{+} \mathrm{CD}^{+} 2 \mathrm{~L}^{+} \mathrm{T}$ central memory cells recirculate through SLOs, CCR7 ${ }^{-} \mathrm{CD}^{-} \mathrm{L}^{-} \mathrm{T}$ effector memory cells traffic through peripheral tissues, and $\mathrm{CD}_{103}{ }^{+} \mathrm{CD} 9^{+} \mathrm{T}$ resident memory cells localize to tissue barriers (25). However, in pathologic conditions involving chronic inflammation, such as autoimmune diseases, cancer, and organ transplantation, the anatomic distinction between inflamed peripheral tissues and lymph node follicles begins to blur. Chronically inflamed sites frequently develop aggregates of $\mathrm{T}$ cells and $\mathrm{B}$ cells that promote $\mathrm{B}$ cell responses locally within the tissue (26). Often these aggregates appear as small, disorganized lymphocyte clusters. In some cases, the aggregates mature into organized ectopic lymphoid structures (ELS, also referred to as tertiary lymphoid organs/tissues/structures) that acquire many features of follicles in SLOs, including compartmentalization of $\mathrm{T}$ cell-rich and $\mathrm{B}$ cell-rich zones and accumulation of follicular dendritic cells (FDC) (26).

$\mathrm{T}$ cell-B cell interactions within chronically inflamed tissues can reproduce many of the key features of productive interactions within SLO follicles, including somatic hypermutation, class switching, and differentiation of plasma cells (26). For example, the inflamed synovium in rheumatoid arthritis (RA) develops lymphoid aggregates, which can range from small clusters to organized follicles with GCs (27). Plasma cells differentiate within these aggregates and are often seen extending out from the borders of the aggregates $(28,29)$. Similarly, somatic hypermutation and differentiation of plasmablasts occurs within tubulointerstitial aggregates in kidneys affected by lupus nephritis (30). Infiltrated tumors and rejecting kidney allografts also show evidence of lymphoid aggregates that support B cell somatic hypermutation despite the absence of typical GC (31-34). The accumulation of lymphocytes and plasma cells in chronically inflamed tissues occurs frequently enough to have merited its own term "lymphoplasmacytic infiltrate," which appears not uncommonly in clinical histopathologic reports.

Defining the T cell populations most relevant for driving B cell aggregation and proliferation within peripheral tissues remains challenging. It has been generally assumed that Tfh cells infiltrate peripheral tissues to drive $\mathrm{B}$ cell responses within these tissues. However, this assumption requires some caution. For one, the migratory receptors required to infiltrate a peripheral tissue differ substantially from those required to access SLOs. CXCR5 ${ }^{+}$Tfh cells typically do not express chemokine receptors that recruit $\mathrm{T}$ cells to inflamed peripheral tissues, such as CCR2, CCR5, and CX3CR1 (1). Rather, a tightly controlled migratory program helps restrict Tfh cells to CXCL13-laden follicles. Thus it is not obvious how Tfh cells would be initially recruited to inflamed sites that lack well-established follicles. This raises the possibility that $\mathrm{T}$ cells with a distinct migratory capacity-directed by expression of a distinct cohort of migratory receptors-may interact with B cells in diffusely inflamed tissues.

Second, lymphocyte populations within inflamed tissues are dominated by memory cells that have undergone prior activation, with a smaller representation of naïve lymphocytes than in SLOs. Both memory $\mathrm{T}$ cells and $\mathrm{B}$ cells differ in their responsiveness to antigen-receptor activation, requirement for costimulation, and sensitivity to cytokines and other inputs as compared to their naive counterparts $(25,35,36)$; thus, the interactions between effector/memory $\mathrm{T}$ cells and $\mathrm{B}$ cells within inflamed tissues may differ from those that occur within follicles of SLOs. Even within the same tonsil, different B cell populations (naïve, 
memory, GC-B cells) yield markedly different responses when co-cultured with distinct tonsil $\mathrm{CD}^{+}{ }^{+} \mathrm{T}$ cell populations: GCTfh strongly promote immunoglobulin production from GC-B cells, yet ICOS ${ }^{\text {low }}$ CXCR $5^{\text {low }}$ T cells fail to do so because the FasL that they produce kills co-cultured GC-B cells (23). In contrast, naïve and memory $B$ cell populations respond well to CXCR5 $5^{\text {low }}$ ICOS $^{\text {low }} \mathrm{T}$ cells because these $\mathrm{B}$ cell populations do not express Fas and are insensitive to FasL (23). Thus the rules of engagement may differ depending on the specific cell types present and the organization of the interactions.

Finally, determining the phenotype of $\mathrm{T}$ cells that help $B$ cells in inflamed tissues faces technical challenges. The tissues that can be obtained are often small, with many fewer lymphocytes available compared to SLOs. In addition, the highly overlapping expression programs between Tfh cells and B cells limit interpretation of total tissue sample analyses (e.g., mRNA from the whole tissue) because one cannot distinguish whether key factors such as CXCR5 and Bcl6 are derived from the $\mathrm{T}$ cells or $\mathrm{B}$ cells. The tightly entangled interaction between $\mathrm{T}$ cells and $\mathrm{B}$ cells in tissues provides challenges for standard immunofluorescence microscopy and even laser capture microscopy (37). Immunohistochemistry and immunofluorescence microscopy allow visualization of $\mathrm{T}$ cell-B cell aggregates and may provide the resolution to discriminate $\mathrm{T}$ cell vs. B cell phenotypes. However, relatively few parameters are measured simultaneously, and discriminating cell surface protein expression (e.g., CXCR5 expression) on the surface of $\mathrm{T}$ cells surrounded by a tight cluster of CXCR5-bright B cells can be difficult. In addition, the cellular source of soluble factors such as IL-21 and CXCL13 can be ambiguous, especially for factors that bind to extracellular matrix (38-40). Utilization of single cell resolution analyses are therefore particularly valuable to interrogate in detail the phenotypes of potential $\mathrm{T}$ cells that help B cells within tissue samples.

\section{B CELL-HELPER T CELLS IN RHEUMATOID ARTHRITIS}

RA synovium provides a valuable case study to interrogate $T$ cell-B cell interactions in a chronically inflamed tissue. RA is an autoimmune disease that prominently features pathologic $\mathrm{T}$ cellB cell interactions. Approximately $2 / 3$ of RA patients develop autoantibodies-antibodies against citrullinated proteins and/or other immunoglobulins (rheumatoid factors). Seropositive RA patients commonly develop $\mathrm{T}$ cell-B cell aggregates within synovial tissue (41). These are often small or mediumsized aggregates, although $\sim 10-15 \%$ of patients develop more organized aggregates with features of GC $(27,42,43)$. Most B cells in RA synovium are CD27+ memory B cells with mutated $B$ cell receptor sequences, although a minority of naïve $B$ cells can also be found within lymphoid aggregates $(28,44,45)$. Synovial B cells produce RA-associated autoantibodies, and B cell receptor repertoire analyses suggest that memory B cells activated in synovial aggregates can differentiate into plasma cells locally within the tissue, even in the absence of GCs $(28,29,46)$. Plasma cells are often found extending out from around lymphoid aggregates (29). In some patients, plasma cells accumulate densely throughout the synovium, which is a defining feature of a highly inflamed RA synovium and can distinguish RA from other causes of early arthritis $(47,48)$.

Given the prominent lymphocyte aggregates and evidence of ongoing B cell activation, RA synovium appears a very likely place for accumulation of Tfh cells to help drive these responses. RA is somewhat unique among human autoimmune diseases in that relatively large samples of the target tissue can be obtained for research. Synovial tissue obtained either at the time of joint replacement surgery or through a researchprotocol biopsy can provide sufficient material for multiple high-dimensional cellular analyses $(41,49)$. Surprisingly, a mass cytometry screen of $\mathrm{T}$ cells isolated from RA synovial tissue performed by our group revealed few $\mathrm{CXCR} 5^{+}$Tfh cells in RA synovium, despite frequent B cells and plasma cells (50). In addition, flow cytometry demonstrated an almost total absence of Tfh cells in RA synovial fluid. However, seropositive RA synovial tissue and fluid samples contained a large population of PD$1^{\text {hi }}$ CXCR $^{-} \mathrm{T}$ cells, comprising $\sim 25 \%$ of the $\mathrm{CD}^{+} \mathrm{T}$ cells, that expressed high levels of IL-21 and CXCL13 and induced memory B cell differentiation into plasma cells in vitro. CXCR5 expression was absent from $\mathrm{PD}-1^{\text {hi }} \mathrm{CXCR}^{-}$cells at both the protein and mRNA level, in contrast to the well-detected CXCR5 expression in tonsil Tfh cells and circulating Tfh cells. PD-1 hi CXCR5 $^{-}$T cells were observed adjacent to B cells both within lymphocyte aggregates and more diffusely throughout inflamed synovium. Like Tfh cells, synovial PD-1 ${ }^{\text {hi }}$ CXCR5 ${ }^{-}$T cells also expressed high levels of ICOS and MAF, a transcription factor that promotes IL-21 production (discussed below). Cytometric and transcriptomic comparisons of PD- $1^{\text {hi }}$ CXCR5 ${ }^{-}$and PD- $1{ }^{\text {hi }}$ $\mathrm{CXCR}^{+}$cells from blood showed high expression of TIGIT, SAP, CD200, and SLAM and low expression of CD25 and CD127 in both populations (50).

However, PD- $1^{\text {hi }}$ CXCR5 ${ }^{-}$T cells also showed key differences from Tfh cells. Unlike Tfh cells, PD- ${ }^{\text {hi }}$ CXCR5 ${ }^{-}$cells from synovium did not express high levels of Bcl6, and instead they showed elevated levels of the counter-regulator Blimp1, which opposes the actions of Bcl6 (10). In addition, PD- ${ }^{\text {hi }}$ cells from synovium not only lacked CXCR5, but they frequently expressed a different cohort of chemokine receptors, including CCR2, CCR5, and CX3CR1, with approximately half of the PD-1 hi cells expressing CCR2 (50). Notably, these receptors are abundant on leukocytes that infiltrate RA synovium, which contains high levels of the CCR2 ligand CCL2 (MCP-1) and the CCR5 ligand RANTES, among others (51-55). These chemokines are so prominent in inflamed synovium that attempts have been made to interfere with both CCR2- and CCR5-mediated trafficking therapeutically to blunt synovium inflammation, although such approaches have not yet succeeded perhaps due to migratory signal redundancy or incomplete signal blockade (56-58).

\section{PERIPHERAL VS. FOLLICULAR B CELL-HELPER T CELLS}

The presence of a B cell-helper T cell population in RA synovium with a $\mathrm{CXCR}^{-} \mathrm{Bcl}^{\text {low }}$ but $\mathrm{CCR}^{+} \mathrm{Blimp1}^{+}$phenotype illustrates that IL-21, CXCL13, and B cell help can be provided by 
T cell populations that differ substantially in phenotype from Tfh cells (Figure 1). Two key points arise from these observations:

1) T cells that help B cells do not necessarily express CXCR5. The RA synovium observations reveal a population of $\mathrm{T}$ cells that home to sites of inflammation, using chemokine receptors that target these sites, and help B cells within these sites. We have suggested that these CXCR5 ${ }^{-}$PD- $1^{\text {hi }}$ T cells can be considered peripheral, rather than follicular, B cell-helper T cells, and we referred to these cells as $\mathrm{T}$ peripheral helper (Tph) cells for shorthand (50). Once activated within inflamed tissues, Tph cells may secrete CXCL13 to recruit B cells (and potentially Tfh cells) and produce IL-21 to help drive B cell survival and maturation.

2) T cells that help B cells do not necessarily express high levels of Bcl6. The Tph cells in RA synovium express modest levels of Bcl6, well below that seen in synovial CXCR5 ${ }^{+}$PD- $1^{\text {hi }} \mathrm{Tfh}$ cells, indicating that $\mathrm{B}$ cell-helper function can be dissociated from high Bcl6 expression. As discussed below, Bcl6 does not directly control production of IL-21 $(11,13)$. Rather, one major role for high Bcl6 levels is directing the positioning of Tfh cells in follicles through upregulation of CXCR5 and downregulation of CCR7, PSGL1, and EBI2 $(13,17)$. High Bcl6 expression also helps CXCR5+ cytotoxic CD8+ T cells localize to follicles (59). This role of Bcl6 in directing $\mathrm{T}$ cells to follicles may be less important for B cell-helper T cells that are present in more diffusely infiltrated tissues without true GC. Bcl6 also importantly controls additional features of Tfh cells, including expression of molecules involved in interacting with B cells (ICOS, PD-1, CD40L); however, it is possible that the lower levels of Bcl6, such as seen in synovial Tph cells, may be sufficient for this function. Other transcriptions factors such as MAF may also co-regulate some of these molecules (13).

B cell-helper T cells have been reported within target tissues in range of autoimmune, inflammatory, and malignant conditions; it will be of substantial interest to now clarify the extent to which these cells resemble Tfh cells vs. Tph cells in each condition. There is no doubt that Th cells play a critical role in providing help to B cells in SLOs, and it is clear Tfh cells infiltrate wellformed ELS with GC in inflamed tissues as well. Yet the following sections highlight selected diseases and models in which evidence suggests the presence of potential B cell-helper T cells-identified by production of IL-21 or CXCL13 - that differ from prototypical Tfh cells. For this discussion, Tfh cells are defined as CXCR5 ${ }^{+}$ $\mathrm{Bcl6}^{+} \mathrm{CD} 4^{+} \mathrm{T}$ cell that produce IL-21 (and CXC13 in humans), while cells that lack CXCR5 or Bcl6 are considered non-Tfh cells and may represent candidate Tph cells.

\section{IL-21-PRODUCING T CELLS IN INFLAMED TISSUES}

Tfh cells produce high levels of IL-21 to stimulate B cell survival and differentiation, thus production of IL-21 is often used as a surrogate marker for Tfh cells. It is important to note that IL-21 can also be produced by other $\mathrm{CD} 4^{+} \mathrm{T}$ cell populations and NKT cells, and that this cytokine acts on many different target cell populations to enhance or tailor responses, for example boosting cytotoxicity of $\mathrm{CD} 8^{+} \mathrm{T}$ cells and NK cells, or altering macrophage function (22). Nonetheless, it seems likely that $\mathrm{T}$ cells that produce IL-21 while in close proximity to B cells,

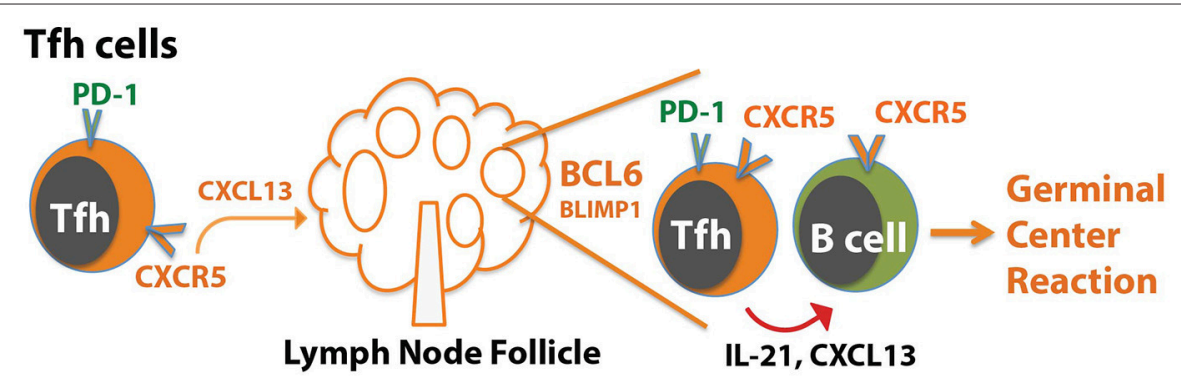

\section{Tph cells}

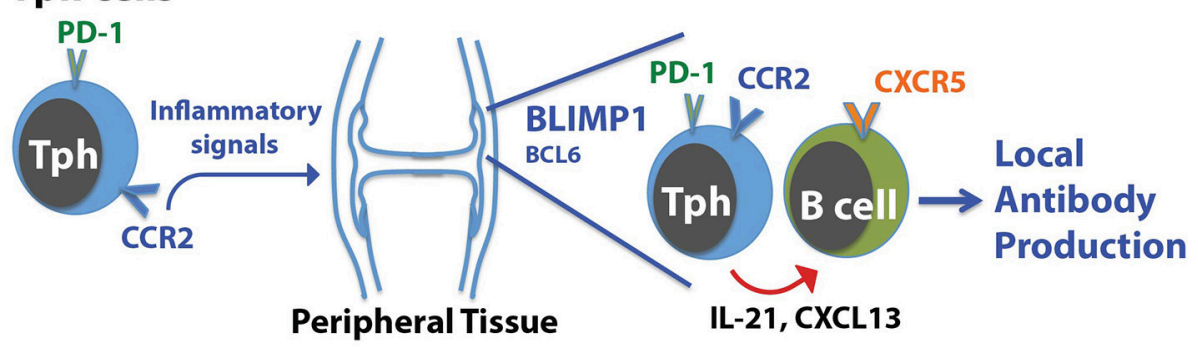

FIGURE 1 | Distinctions between Tph cells and Tfh cells. Tfh cells home to follicles following the chemokine CXCL13, which acts on CXCR5 on the Tfh cells. In contrast, Tph cells express a distinct set of chemokine receptors that direct migration to sites of inflammation, such as the RA joint. In both cases, Tph cells or Tfh cells interact with CXCR5+ B cells by producing CXCL13 to help recruit B cells, and IL-21 to help drive B cell activation and differentiation. For Tfh cells, this promotes generation of a GC reaction in follicles. For Tph cells, this may augment local antibody production within the tissue. 
for example within lymphocyte aggregates, can enhance B cell responses. The following examples suggest that IL-21-producing $\mathrm{CD}^{+} \mathrm{T}$ cells in inflamed tissues can show substantial variability in their expression of Tfh-associated factors.

Transplanted renal and cardiac allografts undergoing rejection can develop ELS with plasma cells that produce donor-specific antibodies $(60,61)$. Renal allografts that undergo rapid rejection contain high mRNA expression of IL-21 (62). IL-21 expression levels correlate strongly with expression of AID, a protein required for somatic hypermutation and class switch recombination in B cells, suggesting a potential connection between T cell-derived IL-21 and B cell activation with the grafts (62). However, IL-21 expression levels in rejected allografts showed no correlation with Bcl6 expression levels, and fewer than $5 \%$ of the $\mathrm{CD}^{+} \mathrm{T}$ cells in rejected allografts expressed CXCR $^{+}$by flow cytometry (62). An independent series of analyses of kidney allografts undergoing acute $\mathrm{T}$ cell-mediated rejection found that the majority of $\mathrm{CD}^{+} \mathrm{T}$ cells within lymphocyte aggregates expressed IL21 by immunofluorescence microscopy, yet few of these $\mathrm{T}$ cells co-expressed $\mathrm{Bcl6}(63,64)$. These observations suggest that $\mathrm{CD}^{+} \mathrm{T}$ cells within lymphocyte aggregates of rejecting allografts produce abundant IL-21, yet the majority of this IL-21 appears to come from non-CXCR5 ${ }^{+} / \mathrm{Bcl}^{+} \mathrm{CD}^{+} \mathrm{T}$ cells.

In multiple sclerosis, an autoimmune disease that involves infiltration of $\mathrm{T}$ cells and $\mathrm{B}$ cells in parenchymal demyelinating lesions, as well as development of lymphoid aggregates in the meninges, a similarly high frequency of IL-21-producing $\mathrm{T}$ cells has been reported (65-67). Immunofluorescence microscopy analyses suggested that more than half of $\mathrm{CD} 4{ }^{+} \mathrm{T}$ cells in both active and chronic parenchymal lesions produce IL-21, while the receptor for IL-21 is expressed broadly on infiltrating B cells and $\mathrm{T}$ cells and on neurons (67). The frequency of CXCR5 ${ }^{+} \mathrm{T}$ cells in these lesions is not yet clear; however, in cerebrospinal fluid from multiple sclerosis patients $\sim 20 \%$ of memory CD $4^{+} \mathrm{T}$ cells express CXCR5, comparable to the frequency observed in blood. While the expression of CXCR5 may differ between cerebrospinal fluid and tissue, these observations raise the possibility that a large portion of the IL- $21^{+} \mathrm{CD} 4^{+} \mathrm{T}$ cells in multiple sclerosis may not express CXCR5.

Analyses of nasal polyps that develop due to chronic upper airway inflammation indicated that $\sim 20-40 \%$ of $\mathrm{CD}^{+} \mathrm{T}$ cells produce IL-21, as observed by both flow cytometry and immunohistochemistry (68-70). CXCR5 ${ }^{-}$effector memory $\mathrm{T}$ cells comprise the majority of the IL-21-producing cells in affected nasal tissues (69). These cells frequently express PD1 and co-produce IFN- $\gamma(69,70)$. CXCR5 ${ }^{+}$Bcl6 $^{+}$Tfh cells are enriched in the lymphoid aggregates that form in these polyps compared to healthy tissue; however, Bcl6 expression is relatively infrequent in nasal polyps overall (perhaps $2-5 \%$ of $\mathrm{CD}^{+}{ }^{+} \mathrm{T}$ cells), with higher frequencies in T cells from polyps that contained GCs or eosinophils (68-70). Thus while it is clear that Tfh cells are enriched in nasal polyps, it is not yet clear that Tfh cells provide the majority of the B cell help in nasal polyps.

In contrast to RA and the conditions above, IgG4-related disease (IgG4-RD) provides an example in which bona fide
GC-Tfh cells appear to dominate the $\mathrm{T}$ cell infiltrate. IgG4$\mathrm{RD}$ involves formation of large, fibrotic lesions that are heavily infiltrated by $\mathrm{IgG}^{+}$plasma cells (71). The lesions can form in several tissues including the salivary glands (sialadenitis) and lacrimal glands (dacryoadenitis) and contain large ELS with GC (72). The majority of $\mathrm{T}$ cells purified from these lesions show a prototypical GC-Tfh phenotype, with expression of CXCR5, Bcl6, PD-1, ICOS, CXCL13, and IL-21 at high levels that equal or exceed that seen in human tonsils $(72,73)$. Interestingly, GCs appear more common in IgG4-RD than in Sjogren's syndrome, an autoimmune disease that also produces lymphoid aggregates in the salivary glands but involves at least in part a CCR9 ${ }^{+} \mathrm{B}$ cell-helper $\mathrm{T}$ cell population with features distinct from Tfh cells (discussed below) $(72,74)$.

Murine models also support the idea that non-Tfh cells can provide important help to B cells via IL-21. In lupus-prone MRL/lpr mice, a population of CXCR $4^{+}$PSGL- ${ }^{\text {low }} \mathrm{CD} 4^{+} \mathrm{T}$ cells accumulates within extrafollicular foci in the spleen to support plasmablast responses (75). These extrafollicular helpers require Bcl6 and ICOS yet express little CXCR5 and do not transmigrate to CXCL13; rather, they express CXCR4, which may help position them in areas of higher CXCL12 concentration such as near the red pulp (75-77). These extrafollicular helper $\mathrm{T}$ cells provide a unique source of IL-21 to promote plasma cell generation and IgG production from B cells in extracellular follicles (75-77). A potentially comparable $\mathrm{T}$ cell population has also been observed in human tonsil, identified as CXCR5 ${ }^{\text {low }} \mathrm{ICOS}^{\text {low }} \mathrm{CD} 4^{+} \mathrm{T}$ cells, although it is difficult to fully distinguish whether these cells are extrafollicular helpers or 'pre-Tfh' cells (23). In vitro, this $\mathrm{CXCR}^{\text {low }} \mathrm{ICOS}^{\text {low }} \mathrm{Bcl}^{\text {low }}$ population efficiently helps naïve and memory B cells via production of IL-21, yet appears to kill, rather than help, GC-B cells via Fas-FasL interactions (23).

Productive interactions between $\mathrm{B}$ cells and non-Tfh cells also occur in inflamed peripheral tissues in murine models. In a chronic lung inflammation model induced by ovalbumin + LPS, large lymphoid aggregates develop in the lungs (78). While occasional aggregates show features of ELS, most appear loose and poorly organized. Interestingly, B cells with GC features, including staining with peanut agglutinin and the monoclonal antibody GL7, were found both in the ELS and in the loose aggregates, suggesting development of GC-like B cells within the lung aggregates; however, no $\mathrm{Bcl}^{+}$or $\mathrm{CXCR} 5^{+} \mathrm{T}$ cells were present in these tissues (78). Rather, high IL-21 production and $\mathrm{B}$ cell-helper activity existed within the CXCR5 ${ }^{-} \mathrm{Bcl} 6^{-} \mathrm{T}$ cell population resident in the lung. While no defined markers were identified to specifically isolate the B cell-helper $\mathrm{T}$ cells out of the total lung $\mathrm{T}$ cell pool, high average expression of PD-1 and ICOS suggest a likely overlap with the Tph cell described in RA synovium. A separate study of a house dust mite-induced murine asthma model also identified a PD- ${ }^{\text {hi }}$ CXCR5 ${ }^{-}$IL-21producing $\mathrm{CD}^{+} \mathrm{T}$ cell population that accumulates in the lungs (79). This $\mathrm{T}$ cell population derived from Tfh cells in lymph nodes and migrated to the lungs to enhance eosinophilic airway inflammation via IL-21.

Observations from the non-obese diabetic (NOD) mouse provide further evidence of $\mathrm{B}$ cell help from non-Tfh cells. NOD mice develop lymphoid aggregates in the pancreas, with 
development of more organized ELS with FDC networks over time (80). The pancreas in NOD mice is infiltrated with an IL21-producing effector memory $\mathrm{CD}^{+} \mathrm{T}$ cell population with high $\mathrm{ICOS}^{+}$expression. Strikingly, the majority of these cells expressed CCR9, a chemokine receptor that confers sensitivity to the chemokine CCL25 and helps mediate migration to mucosal sites such as the small bowel $(81,82)$. Pancreatic CCR9 ${ }^{+}$T cells expressed high levels of Bcl6 and MAF, yet little CXCR5 and SAP and variable $\mathrm{PD}-1$. Consistent with IL-21 production, pancreatic CCR9 $^{+} \mathrm{T}$ cells could enhance immunoglobulin production from co-cultured B cells in vitro (82). IL- $21^{+} \mathrm{CCR}^{+}$cells were also detected in the salivary glands of NOD mice (82). Consistent with these observations, CCR9 ${ }^{+} \mathrm{ICOS}^{+}$cells are present in salivary glands of patients with Sjogren's syndrome, and the levels of the CCR9 ligand CCL25 in salivary tissue correlated positively with the levels of IL-21 and plasma cells in the tissue (83). In addition, human CCR9 $^{+} \mathrm{T}$ cells from blood produced IL-21 at even higher levels than do CXCR5 ${ }^{+} \mathrm{T}$ cells and enhanced responses of co-cultured B cells in vitro (81, 83).

An independent study of NOD mice identified a potentially distinct population of B cell-helper T cells that is highly enriched in infiltrated salivary glands. This $\mathrm{T}$ cell population, identified as PD- ${ }^{\text {hi }}$ ICOS $^{\text {hi }} \mathrm{CD} 3^{\text {hi }} \mathrm{CD} 200^{\text {hi }}$, produced high levels of IL21 and IFN- $\gamma$, suggesting possible B cell-helper function, yet lacked Bcl6 and CXCR5 and also showed low expression of CCR9 (84). Viewed together, these observations suggest the tissues of Sjogren's syndrome patients and NOD mice accumulate IL-21producing $\mathrm{B}$ cell-helper $\mathrm{T}$ cell populations that can lack typical Tfh-associated features such as Bcl6 and CXCR5.

Direct interrogation of Bcl6-deficient $\mathrm{T}$ cells provides further support for effective $\mathrm{B}$ cell help from non-Tfh cells. In a murine influenza model, Th1 $\mathrm{CD}^{+} \mathrm{T}$ cells can promote generation of neutralizing antibodies when Tfh cells are rendered absent due to CD3-specific deletion of Bcl6 (85). In this model, CXCR5 ${ }^{-}$Th1 cells secreted enough IL-21, co-produced with IFN- $\gamma$, to stimulate production of protective, albeit low-affinity, neutralizing antibodies to influenza virus. Bcl6independent production of IL- 21 by $\mathrm{CD} 4{ }^{+} \mathrm{T}$ cells has also been observed in a murine Plasmodium chabaudi infection model, in which CD4-specific deletion of Bcl6 eliminated development of CXCR5 ${ }^{\text {hi }}$ GC-Tfh cells but did not alter production of IL21 in the spleen, which derived primarily from IL-21/IFN- $\gamma$ double producers that retained intermediate CXCR5 expression (86).

\section{REGULATION OF IL-21 PRODUCTION IN T CELLS}

The above examples demonstrate that populations of $\mathrm{T}$ cells with varying degrees of similarity to Tfh cells can produce IL21 and provide B cell help in inflamed tissues. The factors that regulate the ability of $\mathrm{CD} 4^{+} \mathrm{T}$ cells to produce IL-21 differ somewhat between human $\mathrm{T}$ cells and mouse $\mathrm{T}$ cells. In mice, IL-6 and IL-21 potently induce IL-21 production from T cells stimulated in vitro, and IL-21 is frequently detected in cultured of $\mathrm{T}$ cells stimulated under Th17-polarizing conditions $(22,87-$ 89). In contrast, IL-6 and IL-21 do not efficiently induce IL21 production by human $\mathrm{CD}^{+}{ }^{+} \mathrm{T}$ cells; IL-12 is far more potent in promoting IL-21 production by human $\mathrm{T}$ cells and often induces IFN- $\gamma / \mathrm{IL}-21$ co-producers $(90,91)$. IL-12 can also enhance IL-21 production by murine $\mathrm{CD} 4^{+} \mathrm{T}$ cells, which transit through an early Tfh-like phenotype when stimulated under Th1inducing conditions (92). In addition, IL-12 transiently enhances expression of Bcl6, CXCR5, and ICOS via STAT4; this effect is subsequently suppressed by Tbet (92). The overlap between Tfh and Th1 features in T cells early after activation appears to fit well with the theme that IL-21-producing $\mathrm{T}$ cells in inflamed tissues often also show Th1 features and co-produce IFN- $\gamma$.

Importantly, transcriptional control of IL-21 production occurs largely independently of Bcl6. Murine $\mathrm{CD} 4^{+} \mathrm{T}$ cells that lack Bcl6 produce IL-21 at normal levels, and overexpression of Bcl6 in murine $\mathrm{T}$ cells does not increase IL-21 production (11). Similarly, overexpression of Bcl6 in human tonsil $\mathrm{CD}^{+}$ $\mathrm{T}$ cells does not alter IL-21 production (13). Instead, the transcription factor MAF, which is highly expressed in both Tfh cells and synovial Tph cells, appears most directly associated with IL-21 production. In vitro, MAF can activate an IL-21 promoter-luciferase reporter construct, unlike Tbet or GATA3, and overexpression of MAF in human tonsil $\mathrm{CD}^{+}{ }^{+} \mathrm{T}$ cells or mouse naïve $\mathrm{CD}^{+} \mathrm{T}$ cells increases IL-21 production (13, 93, 94). In addition, genetic deletion of MAF reduces IL-21 production from murine Th17 cells (95). Interestingly, in human $\mathrm{T}$ cells, the combination of IL-12 plus TGF- $\beta$ induces several features of Tfh cells, including increased expression of IL-21, MAF, Bcl6, and CXCR5 (91). This occurs as TGF- $\beta$ directs the actions of STAT4 and STAT3, activated by IL-12, to enhance Tfh cell features (91). TGF- $\beta$ also induces MAF in murine CD4 ${ }^{+}$ $\mathrm{T}$ cells, yet it concurrently inhibits IL-21 production and does not promote a Tfh phenotype in murine $\mathrm{T}$ cells $(91,93)$. A more comprehensive delineation of the signals that control IL21 production, along with other factors required for cell-surface interactions with $\mathrm{B}$ cells, will be valuable to better understand the regulation of T cell-B cell interactions in the periphery.

\section{CXCL13-PRODUCING T CELLS IN INFLAMED TISSUES}

While IL-21 can be produced broadly by different $\mathrm{T}$ cell populations and may act on diverse target cells, production of CXCL13 appears to be a much more specific marker of $\mathrm{T}$ cell-B cell interactions. CXCL13 acts specifically to recruit and position $\mathrm{CXCR} 5^{+}$cells within lymphoid follicles, primarily B cells and Tfh cells $(2-4,8,96)$. Overexpression of CXCL13 in a peripheral tissue induces formation of $\mathrm{B}$ cell aggregates that eventually mature into ELS, while neutralization of CXCL13 in murine models reduces lymphoid aggregate formation and tissue inflammation severity in several chronic inflammation models (97-103). Consistent with these observations, the highest expression of CXCR5 in RA synovium is found on B cells, with bright CXCR5 expression seen on B cells within synovial aggregates (50). 
Importantly, Tfh cells from humans and primates, but not rodents, produce large amounts of CXCL13 $(1,7,18)$. In lymph nodes, GC-Tfh cells are an important, and perhaps primary, source of CXCL13. Immunohistochemistry of tonsils shows costaining of CXCL13 primarily with $\mathrm{PD}-1^{+} \mathrm{T}$ cells, rather than CD21 ${ }^{+}$FDCs, within follicles $(104,105)$. Intracellular flow cytometry of human inguinal lymph node cells also showed expression of CXCL13 primarily in PD- $1^{\text {hi }}$ CXCR5 ${ }^{\text {hi }}$ GC-Tfh cells, with few $\mathrm{CXCL}^{+}{ }^{+}$cells among other $\mathrm{T}$ cell populations, B cells, or stromal cells (106). Further, the frequency of GC-Tfh cells in lymph nodes correlates positively with serum CXCL13 levels in both humans and non-human primates, such that the serum CXCL13 level has been suggested to represent a biomarker of total GC activity. If cells produce CXCL13 in order to recruit B cells (which express high levels of CXCR5, the only known receptor for CXCL13), then CXCL13-producing T cells (GC-Tfh cells and others) are prime candidates to interact with $\mathrm{B}$ cells in various settings.

While GC-Tfh cells are a major source of CXCL13 in lymph nodes, there are accumulating data that non-Tfh cells with varied surface phenotypes can produce CXCL13 at different sites. In Sjogren's syndrome patients, CCR9 ${ }^{+} \mathrm{CXCR}^{-} \mathrm{T}$ cells from the blood produced CXCL13 (in addition to IL-21 as described above), albeit at lower levels than was produced by CXCR5 $^{+}$cells (83). CXCL13 production from $\mathrm{CD}^{+} \mathrm{T}$ cells in RA synovium was first described by Manzo et al., who noted CXCL13 ${ }^{+} \mathrm{CD}^{+} \mathrm{T}$ cells both in areas of large lymphoid aggregates and also in areas with smaller aggregates or diffuse lymphocyte infiltration (107). Flow cytometry of synovial fluid $\mathrm{T}$ cells revealed that most $\mathrm{CXCL13}{ }^{+} \mathrm{T}$ cells are memory $\mathrm{CD} 4^{+} \mathrm{T}$ cells that lack CXCR5 and contain little Bcl6. These CXCL13 ${ }^{+} \mathrm{T}$ cells were often CD27 negative, suggesting a chronically activated or terminally differentiated phenotype (107). An independent study identified the same population of $\mathrm{CXCL} 13^{+} \mathrm{CD} 4^{+} \mathrm{T}$ cells with little CXCR5 or Bcl6 expression, but with high expression of PD-1 (108). Detailed assessments by mass cytometry, RNAseq transcriptomics, and in vitro B cell-helper assays then defined this synovial $\mathrm{T}$ cell population as Tph cells (50).

Single cell RNA-seq analyses of synovial tissue have recently highlighted Tph cells as the predominant source of CXCL13 in rheumatoid synovium. The vast majority of CXCL13 signal in RA synovium detected by single cell RNA-seq is in the Tph cell population, with little CXCL13 detected in synovial fibroblasts, macrophages, vascular cells, or B cells (109). This powerful analysis provides a high-resolution view of the potential cellular sources of CXCL13 in the tissue, which can be difficult to discern from immunohistochemical analysis given that CXCL13 can deposit on matrix components once secreted (40). CXCL13 has emerged as a promising biomarker in RA, with its level in the synovium associated with the presence of synovial lymphoid aggregates, autoantibody positivity, and erosive disease (110, 111). In this context, it is remarkable that the majority of this CXCL13 appears to come from infiltrating Tph cells (109). Notably, CXCL13 production by human B cell-helper T cells stands in stark contrast to the murine Tfh cells, which do not make CXCL13. Rather, stromal and parenchymal cells appear to be the major producers of CXCL13 in murine tissues, stimulated by lymphotoxin $\alpha / \beta$ and TNF in SLOs or IL-17A in inflamed tissues $(112,113)$.

Single cell RNA-seq analyses appear to be particularly sensitive in identifying $\mathrm{CXCL}^{+}{ }^{+} \mathrm{T}$ cell populations, perhaps because CXCL13 mRNA transcripts are expressed at very high levels in restricted subpopulations of cells $(50,109)$. RNA-seq of single cell $\mathrm{T}$ cells sorted from hepatocellular carcinoma samples identified an easily distinguished $\mathrm{CXCL}_{13}{ }^{+} \mathrm{CD}^{+} \mathrm{T}$ cell population isolated from tumor tissue (114). The chemokine receptor expression on this $\mathrm{T}$ cell population (e.g., CXCR5) was not evaluated in this study; however, an independent study of $\mathrm{T}$ cell infiltrates in hepatocellular carcinoma identified a prominent IL-21-producing $\mathrm{T}$ cell population that accumulates within the peritumoral stroma (115). These cells, which are CXCR5 ${ }^{-}$PD$1^{\text {low }}$, comprise $\sim 10 \%$ of tumor $\mathrm{CD} 4^{+} \mathrm{T}$ cells, and their frequency correlates positively with plasma cell infiltrates and negatively with overall survival (115). Whether the CXCL13 ${ }^{+}$cells seen by RNA-seq and IL- $21^{+}$T cells detected by flow cytometry represent the same $\mathrm{T}$ cell population in hepatocellular carcinoma will be of interest to resolve.

Detailed studies of breast cancer tissue have also revealed a population of infiltrating CXCL13 ${ }^{+} \mathrm{CD}^{+} \mathrm{T}$ cells $(105,116)$. In breast cancer tissue, $\mathrm{CXCL} 13^{+} \mathrm{CD}^{+}{ }^{+} \mathrm{T}$ cells accumulate either within small B cell aggregates, adjacent to B cell follicles, or occasionally within B cell follicles $(105,116)$. These CXCL13 ${ }^{+}$ $\mathrm{T}$ cells display a PD- $1^{\text {hi }}$ ICOS $^{\text {mid }}$ CXCR5 ${ }^{-}$surface phenotype and express high Tbet but relatively low Bcl6 levels compared to tonsil GC-Tfh cells (105). In addition to elevated CXCL13, these cells showed high expression of IL-21, IFN- $\gamma$, and IL10. The presence of CXCL13 ${ }^{+} \mathrm{T}$ cells in breast cancer tissue was found to be a good prognostic sign, associated with a higher rate of disease-free survival (105). While most CXCL13 ${ }^{+}$ $\mathrm{T}$ cells in breast cancer samples are $\mathrm{CD}^{+} \mathrm{T}$ cells, a subset of tumor-infiltrating $\mathrm{CD}^{+} \mathrm{T}$ cells was also noted to produce CXCL13 and reside near $\mathrm{B}$ cell follicles, albeit with lower CXCL13 expression than in $\mathrm{CD}^{+} \mathrm{T}$ cells (105). CXCL13 expression has also been observed in $\mathrm{CD}_{103}{ }^{+} \mathrm{CD}^{+} \mathrm{T}$ cells in ovarian cancer tumors (117). It will be interest to evaluate further the relative contributions, and functional overlap, of $\mathrm{CD}^{+}$and $\mathrm{CD}^{+} \mathrm{T}$ cells that produce CXCL13. Notably, $\mathrm{CD} 4+\mathrm{T}$ cells with $\mathrm{B}$ cell-helper features, including high expression of PD-1, ICOS, and CXCL13, are enriched in multiple solid tumors and in murine tumor model, and these cells are preferentially expanded by anti-CTLA4 but not anti-PD1 therapy (118-120). Clarifying the beneficial vs. deleterious roles of these cells in anti-tumor immune responses will be important in order to utilize this population as a predictive biomarker.

\section{REGULATION OF CXCL13 PRODUCTION IN T CELLS}

Compared to other effector functions, relatively little is known about the regulation of CXCL13 production in human $\mathrm{CD}^{+}$ $\mathrm{T}$ cells. Triggering of the $\mathrm{T}$ cell receptor plus the $\mathrm{CD} 28$ costimulatory receptor on synovial $\mathrm{CD} 4^{+} \mathrm{T}$ cells augments 
CXCL13 secretion (107). Secretion of CXCL13 by synovial T cells appears relatively long-lived and can be sustained for several days by the addition of TNF + IL-6 to in vitro cultures (108). CXCL13producing synovial $\mathrm{CD} 4^{+} \mathrm{T}$ cells show a stable phenotype and are able to retain the ability to produce CXCL13 for several weeks in culture (108). Interestingly, overexpression of Bcl6 enhances production of CXCL13 production by human tonsil $\mathrm{CD}^{+} \mathrm{T}$ cells, suggesting that Bcl6 controls not only the localization of Tfh cells, but also their ability to direct co-localization of B cells (13). Recruitment of B cells through CXCL13 production may act in synergy with upregulation of molecules involved in the T cell-B cell interaction, such as CD40L, PD-1, and ICOS, by Bcl6 (13).

Signals that induce naïve $\mathrm{CD} 4^{+} \mathrm{T}$ cells to acquire the ability to produce CXCL13 are not well defined. TGF- $\beta$ appears important, as treatment of naïve $\mathrm{CD} 4{ }^{+} \mathrm{T}$ cells with TGF- $\beta$ during in vitro stimulation promotes CXCL13 production $(105,121)$. Activin A, which signals through the Activin A receptor to activate Smad2Smad3 pathways in a manner similar to TGF- $\beta$, also promotes CXCL13 production (122). CXCL13 production has also been detected from in vitro differentiated Th17 clones, which may be a consequence of the TGF- $\beta$ used in the Th17 differentiation culture conditions (123). In addition, as with differentiation of mouse Tfh cells, IL-2-induced activation of STAT5 inhibits the
CXCL13-producing phenotype in human $\mathrm{CD}^{+} \mathrm{T}$ cells (105, 121).

\section{TPH CELLS AS POTENTIAL INSTIGATORS OF ELS}

Production of CXCL13 by $\mathrm{T}$ cells that infiltrate an inflamed peripheral tissue may be a key step in the initiation of ELS formation, providing an early stimulus to recruit $\mathrm{CXCR} 5^{+} \mathrm{B}$ cells (Figure 2). Proposed here is a model in which Tph cells infiltrate a site of peripheral inflammation, drawn in by chemokines such as a CCL2, CCL5, and CX3CL1. Upon encountering antigen plus inflammatory cytokines within the tissue, Tph cells produce large amounts of CXCL13, which help recruit $\mathrm{CXCR} 5^{+} \mathrm{B}$ cells into the tissue and draw them into close proximity with the Tph cells. This process may induce formation of the small lymphocyte aggregates frequently observed in inflamed tissues. Recognition of antigen presented on antigen presenting cells within the tissue, including perhaps on recruited B cells, also induces Tph cell production of IL-21, which helps drive maturation and survival of local B cells. If the reaction occurs vigorously enough, then continued production of CXCL13 and IL-21 will recruit and

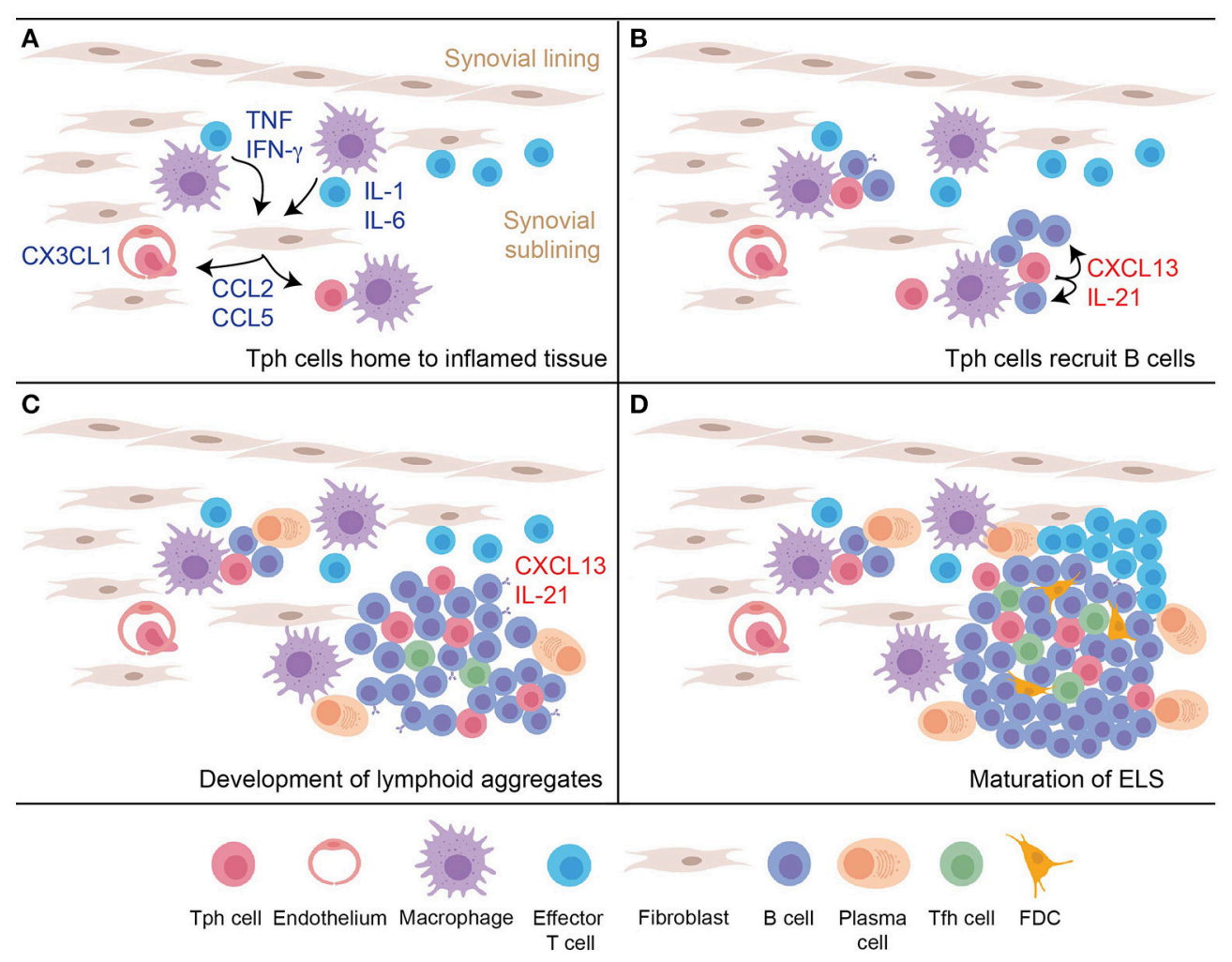

FIGURE 2 | A model for nucleation of ELS in inflamed tissues by Tph cells. (A) An inflammatory response in the peripheral tissue induces production of chemokines and additional signals to recruit peripheral-homing Tph cells. (B) After infiltrating the tissue, activated Tph cells produce CXCL13 to recruit B cells, and produce IL-21 to promote B cell activation and survival. (C) Continued activation of Tph cells and interaction with B cells leads to development of loose lymphoid aggregates, which support some plasma cell differentiation. Tfh cells begin to be recruited into these aggregates in part due to CXCL13 production. (D) Ongoing T cell-B cell interactions and CXCL13 production leads to further maturation of the lymphoid aggregate into organized follicles that acquires features of GC, including accumulation of FDC. 
sustain additional B cells and Tfh cells, as well as eventually FDCs, to yield development of mature ELS. In this model, disrupting the function of Tph cells may abrogate formation of both small and large lymphocyte aggregates within inflamed tissues.

\section{QUESTIONS RAISED}

Many questions remain to understand the range of $\mathrm{B}$ cellhelper $\mathrm{T}$ cells that drive $\mathrm{B}$ cell responses in peripheral tissues. $\mathrm{T}$ cells with Tfh-like features have been identified in target tissues in several diseases and models beyond those discussed here, including lupus, autoimmune hepatitis, primary biliary sclerosis, systemic sclerosis, Hashimoto's thyroiditis and several others (37, 124-127). Detailed phenotypic analyses of these cells in different inflammatory conditions will be of tremendous interest in understanding the features of $\mathrm{B}$ cell-helper $\mathrm{T}$ cells across diseases. For conditions in which both Tfh cells and Tph cells accumulate in inflamed tissues, the more challenging question will be to determine the relative roles, and potentially distinct functions, of these two B cell-helper populations in the involved tissue.

The developmental relationship between Tfh cells and Tph cells is also a key topic to be clarified. It is possible that a subset of Tfh cells differentiate into Tph cells during the GC response. Alternatively, Tph cells may derive from peripheral effector cells that acquire B cell-helper function. Sorted human CXCR5+ Tfh cells and CCR2 + Tph cells remain relatively distinct after short-term in vitro stimulation (50); however, the developmental relationships between these cells may be most definitively addressed in murine models. In addition, it will be of interest to consider where Tph cells fall within the range of $\mathrm{B}$ cell-helper $\mathrm{T}$ cells observed in SLOs, which include GC-Tfh, pre-Tfh, and extrafollicular helpers. For example, do these populations comprise a spectrum of B cell-helper cells distinguished by migratory programs, with Tph cells on one far end and GC-Tfh at the other? Additional questions raised by these observations include: Do Tph cells have a role in

\section{REFERENCES}

1. Crotty S. Follicular helper CD4 T cells (TFH). Ann Rev Immunol. (2011) 29:621-63. doi: 10.1146/annurev-immunol-031210-101400

2. Forster R, Mattis AE, Kremmer E, Wolf E, Brem G, Lipp M. A putative chemokine receptor, BLR1, directs B cell migration to defined lymphoid organs and specific anatomic compartments of the spleen. Cell (1996) 87:1037-47. doi: 10.1016/S0092-8674(00)81798-5

3. Gunn MD, Ngo VN, Ansel KM, Ekland EH, Cyster JG, Williams LT. A B-cellhoming chemokine made in lymphoid follicles activates Burkitt's lymphoma receptor-1. Nature (1998) 391:799-803. doi: 10.1038/35876

4. Legler DF, Loetscher M, Roos RS, Clark-Lewis I, Baggiolini M, Moser B. B cell-attracting chemokine 1, a human CXC chemokine expressed in lymphoid tissues, selectively attracts B lymphocytes via BLR1/CXCR5.J Exp Med. (1998) 187:655-60. doi: 10.1084/jem.187.4.655

5. Ansel KM, McHeyzer-Williams LJ, Ngo VN, McHeyzer-Williams MG, Cyster JG. In vivo-activated CD4 T cells upregulate CXC chemokine receptor 5 and reprogram their response to lymphoid chemokines. J Exp Med. (1999) 190:1123-34. doi: 10.1084/jem.190.8.1123 protective immune responses, or do they primarily mediate chronic, pathologic T cell-B cell interactions? Can Tph cells or peripheral $\mathrm{T}$ cell-B cell interactions be specifically targeted to blunt pathologic inflammatory responses?

\section{CONCLUSION}

While much emphasis has been placed on the central role of Tfh cells in providing $\mathrm{B}$ cell help, the phenotypes of $\mathrm{B}$ cell-helper $\mathrm{T}$ cells in inflamed tissues can differ substantially from Th cells. A focus on $\mathrm{CXCR}^{+}$and $\mathrm{Bcl} 6^{\mathrm{hi}} \mathrm{T}$ cell populations may miss large populations of $\mathrm{B}$ cell-helper $\mathrm{T}$ cells in target tissues, such as the PD- ${ }^{\text {hi }} \mathrm{CXCR}^{-}$Tph cell population in RA synovium. A broad assessment of $\mathrm{T}$ cells that produce the relevant effector molecules and demonstrate B cell-helper function, aided by high-dimensional analyses such as mass cytometry and RNAseq, will provide a more complete understanding of the $\mathrm{T}$ cell-B cell interactions that promote immune-mediated tissue inflammation and the development of ELS in chronically inflamed tissues.

\section{AUTHOR CONTRIBUTIONS}

The author confirms being the sole contributor of this work and approved it for publication.

\section{ACKNOWLEDGMENTS}

DR is supported by the Rheumatology Research Foundation Tobe and Stephen E. Malawista, MD Endowment in Academic Rheumatology and by the National Institute of Arthritis and Musculoskeletal and Skin Diseases of the National Institutes of Health under Award Number K08 AR072791-01. The author thanks Michael Brenner and Alexandra Bocharnikov for helpful discussions. The content is solely the responsibility of the author and does not necessarily represent the official views of the National Institutes of Health.

6. Breitfeld D, Ohl L, Kremmer E, Ellwart J, Sallusto F, Lipp M, et al. Follicular B helper T cells express CXC chemokine receptor 5, localize to B cell follicles, and support immunoglobulin production. J Exp Med. (2000) 192:1545-52. doi: 10.1084/jem.192.11.1545

7. Kim CH, Rott LS, Clark-Lewis I, Campbell DJ, Wu L, Butcher EC. Subspecialization of CXCR5 $+\mathrm{T}$ cells: B helper activity is focused in a germinal center-localized subset of CXCR5+ T cells. J Exp Med. (2001) 193:1373-81. doi: 10.1084/jem.193.12.1373

8. Schaerli P, Willimann K, Lang AB, Lipp M, Loetscher P, Moser B. CXC chemokine receptor 5 expression defines follicular homing $\mathrm{T}$ cells with B cell helper function. J Exp Med. (2000) 192:1553-62. doi: 10.1084/jem.192.11.1553

9. Liu X, Chen X, Zhong B, Wang A, Wang X, Chu F, et al. Transcription factor achaete-scute homologue 2 initiates follicular T-helpercell development. Nature (2014) 507:513-8. doi: 10.1038/nature 12910

10. Johnston RJ, Poholek AC, DiToro D, Yusuf I, Eto D, Barnett B, et al. Bcl6 and Blimp-1 are reciprocal and antagonistic regulators of $\mathrm{T}$ follicular helper cell differentiation. Science (2009) 325:1006-10. doi: 10.1126/science.1175870 
11. Nurieva RI, Chung Y, Martinez GJ, Yang XO, Tanaka S, Matskevitch TD, et al. Bcl6 mediates the development of T follicular helper cells. Science (2009) 325:1001-5. doi: 10.1126/science.1176676

12. Yu D, Rao S, Tsai LM, Lee SK, He Y, Sutcliffe EL, et al. The transcriptional repressor Bcl-6 directs T follicular helper cell lineage commitment. Immunity (2009) 31:457-68. doi: 10.1016/j.immuni.2009.07.002

13. Kroenke MA, Eto D, Locci M, Cho M, Davidson T, Haddad EK, et al. Bcl6 and Maf cooperate to instruct human follicular helper CD4 T cell differentiation. J Immunol. (2012) 188:3734-44. doi: 10.4049/jimmunol. 1103246

14. Hardtke S, Ohl L, Forster R. Balanced expression of CXCR5 and CCR7 on follicular T helper cells determines their transient positioning to lymph node follicles and is essential for efficient B-cell help. Blood (2005) 106:1924-31. doi: 10.1182/blood-2004-11-4494

15. Haynes NM, Allen CD, Lesley R, Ansel KM, Killeen N, Cyster JG. Role of CXCR5 and CCR7 in follicular Th cell positioning and appearance of a programmed cell death gene-1high germinal center-associated subpopulation. J Immunol. (2007) 179:5099-108. doi: 10.4049/jimmunol.179.8.5099

16. Xu H, Li X, Liu D, Li J, Zhang X, Chen X, et al. Follicular T-helper cell recruitment governed by bystander $\mathrm{B}$ cells and ICOS-driven motility. Nature (2013) 496:523-7. doi: 10.1038/nature12058

17. Hatzi K, Nance JP, Kroenke MA, Bothwell M, Haddad EK, Melnick A, et al. BCL6 orchestrates Tfh cell differentiation via multiple distinct mechanisms. J Exp Med. (2015) 212:539-53. doi: 10.1084/jem.20141380

18. Rasheed AU, Rahn HP, Sallusto F, Lipp M, Muller G. Follicular B helper $\mathrm{T}$ cell activity is confined to CXCR5(hi)ICOS(hi) CD4 T cells and is independent of CD57 expression. Eur J Immunol. (2006) 36:1892-903. doi: 10.1002/eji.200636136

19. Chevalier N, Jarrossay D, Ho E, Avery DT, Ma CS, Yu D, et al. CXCR5 expressing human central memory CD4T cells and their relevance for humoral immune responses. J Immunol. (2011) 186:5556-68. doi: 10.4049/jimmunol.1002828

20. Chtanova T, Tangye SG, Newton R, Frank N, Hodge MR, Rolph MS, et al. T follicular helper cells express a distinctive transcriptional profile, reflecting their role as non-Th1/Th2 effector cells that provide help for B cells. $J$ Immunol. (2004) 173:68-78. doi: 10.4049/jimmunol.173.1.68

21. Zotos D, Coquet JM, Zhang Y, Light A, D'Costa K, Kallies A, et al. IL-21 regulates germinal center $B$ cell differentiation and proliferation through a B cell-intrinsic mechanism. J Exp Med. (2010) 207:365-78. doi: $10.1084 /$ jem. 20091777

22. Spolski R, Leonard WJ. Interleukin-21: basic biology and implications for cancer and autoimmunity. Ann Rev Immunol. (2008) 26:57-79. doi: 10.1146/annurev.immunol.26.021607.090316

23. Bentebibel SE, Schmitt N, Banchereau J, Ueno H. Human tonsil B-cell lymphoma 6 (BCL6)-expressing CD4+ T-cell subset specialized for B-cell help outside germinal centers. Proc Natl Acad Sci USA. (2011) 108:E488-97. doi: 10.1073/pnas. 1100898108

24. Campbell DJ, Kim CH, Butcher EC. Separable effector T cell populations specialized for B cell help or tissue inflammation. Nat Immunol. (2001) 2:876-81. doi: 10.1038/ni0901-876

25. Mueller SN, Gebhardt T, Carbone FR, Heath WR. Memory T cell subsets, migration patterns, and tissue residence. Ann Rev Immunol. (2013) 31:13761. doi: 10.1146/annurev-immunol-032712-095954

26. Pitzalis C, Jones GW, Bombardieri M, Jones SA. Ectopic lymphoid-like structures in infection, cancer and autoimmunity. Nat Rev. (2014) 14:447-62. doi: 10.1038/nri3700

27. Takemura S, Braun A, Crowson C, Kurtin PJ, Cofield RH, O'Fallon WM, et al. Lymphoid neogenesis in rheumatoid synovitis. J Immunol. (2001) 167:1072-80. doi: 10.4049/jimmunol.167.2.1072

28. Scheel T, Gursche A, Zacher J, Haupl T, Berek C. V-region gene analysis of locally defined synovial B and plasma cells reveals selected B cell expansion and accumulation of plasma cell clones in rheumatoid arthritis. Arthr Rheumat. (2011) 63:63-72. doi: 10.1002/art.27767

29. Humby F, Bombardieri M, Manzo A, Kelly S, Blades MC, Kirkham B, et al. Ectopic lymphoid structures support ongoing production of classswitched autoantibodies in rheumatoid synovium. PLoS Med. (2009) 6:e1. doi: 10.1371/journal.pmed.0060001
30. Chang A, Henderson SG, Brandt D, Liu N, Guttikonda R, Hsieh C, et al. In situ B cell-mediated immune responses and tubulointerstitial inflammation in human lupus nephritis. J Immunol. (2011) 186:1849-60. doi: 10.4049/jimmunol.1001983

31. Cipponi A, Mercier M, Seremet T, Baurain JF, Theate I, van den Oord J, et al. Neogenesis of lymphoid structures and antibody responses occur in human melanoma metastases. Cancer Res. (2012) 72:3997-4007. doi: 10.1158/0008-5472.CAN-12-1377

32. Coronella JA, Spier C, Welch M, Trevor KT, Stopeck AT, Villar H, et al. Antigen-driven oligoclonal expansion of tumor-infiltrating B cells in infiltrating ductal carcinoma of the breast. J Immunol. (2002) 169:1829-36. doi: 10.4049/jimmunol.169.4.1829

33. Nzula S, Going JJ, Stott DI. Antigen-driven clonal proliferation, somatic hypermutation, and selection of B lymphocytes infiltrating human ductal breast carcinomas. Cancer Res. (2003) 63:3275-80. Available online at: http:// cancerres.aacrjournals.org/content/63/12/3275.long

34. Ferdman J, Porcheray F, Gao B, Moore C, DeVito J, Dougherty $\mathrm{S}$, et al. Expansion and somatic hypermutation of B-cell clones in rejected human kidney grafts. Transplantation (2014) 98:766-72. doi: 10.1097/TP.0000000000000124

35. Sprent J, Surh CD. T cell memory. Ann Rev Immunol. (2002) 20:551-79. doi: 10.1146/annurev.immunol.20.100101.151926

36. Weisel F, Shlomchik M. Memory B cells of mice and humans. Ann Rev Immunol. (2017) 35:255-84. doi: 10.1146/annurev-immunol-041015-055531

37. Liarski VM, Kaverina N, Chang A, Brandt D, Yanez D, Talasnik L, et al. Cell distance mapping identifies functional $\mathrm{T}$ follicular helper cells in inflamed human renal tissue. Sci Trans Med. (2014) 6:230ra46. doi: 10.1126/scitranslmed.3008146

38. Cohen-Kaminsky S, Ranchoux B, Perros F. CXCL13 in tertiary lymphoid tissues: sites of production are different from sites of functional localization. Am J Respir Crit Care Med. (2014) 189:369-70. doi: 10.1164/rccm.201307-1389LE

39. Litsiou E, Semitekolou M, Galani IE, Morianos I, Tsoutsa A, Kara P, et al. CXCL13 production in B cells via Toll-like receptor/lymphotoxin receptor signaling is involved in lymphoid neogenesis in chronic obstructive pulmonary disease. Am J Respir Crit Care Med. (2013) 187:1194-202. doi: 10.1164/rccm.201208-1543OC

40. Yang BG, Tanaka T, Jang MH, Bai Z, Hayasaka H, Miyasaka M. Binding of lymphoid chemokines to collagen IV that accumulates in the basal lamina of high endothelial venules: its implications in lymphocyte trafficking. $J$ Immunol. (2007) 179:4376-82. doi: 10.4049/jimmunol.179.7.4376

41. Orr C, Najm A, Biniecka M, McGarry T, Ng CT, Young F, et al. Synovial immunophenotype and anti-citrullinated peptide antibodies in rheumatoid arthritis patients: relationship to treatment response and radiologic prognosis. Arthr Rheumatol. (2017) 69:2114-23. doi: 10.1002/art. 40218

42. Manzo A, Bombardieri M, Humby F, Pitzalis C. Secondary and ectopic lymphoid tissue responses in rheumatoid arthritis: from inflammation to autoimmunity and tissue damage/remodeling. Immunol Rev. (2010) 233:267-85. doi: 10.1111/j.0105-2896.2009.00861.x

43. Pitzalis C, Kelly S, Humby F. New learnings on the pathophysiology of RA from synovial biopsies. Curr Opin Rheumatol. (2013) 25:334-44. doi: 10.1097/BOR.0b013e32835fd8eb

44. Berek C, Kim HJ. B-cell activation and development within chronically inflamed synovium in rheumatoid and reactive arthritis. Sem Immunol. (1997) 9:261-8. doi: 10.1006/smim.1997.0076

45. Nanki T, Takada K, Komano Y, Morio T, Kanegane H, Nakajima A, et al. Chemokine receptor expression and functional effects of chemokines on $\mathrm{B}$ cells: implication in the pathogenesis of rheumatoid arthritis. Arthr Res Ther. (2009) 11:R149. doi: 10.1186/ar2823

46. Rosengren S, Wei N, Kalunian KC, Zvaifler NJ, Kavanaugh A, Boyle DL. Elevated autoantibody content in rheumatoid arthritis synovia with lymphoid aggregates and the effect of rituximab. Arthr Res Ther. (2008) 10:R105. doi: 10.1186/ar2497

47. Kraan MC, Haringman JJ, Post WJ, Versendaal J, Breedveld FC, Tak PP. Immunohistological analysis of synovial tissue for differential diagnosis in early arthritis. Rheumatology (1999) 38:1074-80. doi: 10.1093/rheumatology/38.11.1074 
48. Orange DE, Agius P, DiCarlo EF, Robine N, Geiger H, Szymonifka J, et al. Identification of three rheumatoid arthritis disease subtypes by machine learning integration of synovial histologic features and RNA Sequencing Data. Arthr Rheumatol. (2018) 70:690-701. doi: 10.1002/art.40428

49. Donlin LT, Rao DA, Wei K, Slowikowski K, McGeachy MJ, Turner JD, et al. Methods for high-dimensional analysis of cells dissociated from cryopreserved synovial tissue. Arthritis Res Ther. (2018) 20:139. doi: 10.1186/s13075-018-1631-y

50. Rao DA, Gurish MF, Marshall JL, Slowikowski K, Fonseka CY, Liu Y, et al. Pathologically expanded peripheral $\mathrm{T}$ helper cell subset drives $\mathrm{B}$ cells in rheumatoid arthritis. Nature (2017) 542:110-4. doi: 10.1038/nature 20810

51. Koch AE, Kunkel SL, Harlow LA, Johnson B, Evanoff HL, Haines GK, et al. Enhanced production of monocyte chemoattractant protein-1 in rheumatoid arthritis. J Clin Invest. (1992) 90:772-9. doi: 10.1172/JCI115950

52. Katschke KJ Jr, Rottman JB, Ruth JH, Qin S, Wu L, LaRosa G, et al. Differential expression of chemokine receptors on peripheral blood, synovial fluid, and synovial tissue monocytes/macrophages in rheumatoid arthritis. Arthr Rheumat. (2001) 44:1022-32. doi: 10.1002/15290131(200105)44:5<1022::AID-ANR181>3.0.CO;2-N

53. Ruth JH, Rottman JB, Katschke KJ Jr, Qin S, Wu L, LaRosa G, et al. Selective lymphocyte chemokine receptor expression in the rheumatoid joint. Arthr Rheumat. (2001) 44:2750-60. doi: 10.1002/15290131(200112)44:12<2750::AID-ART462>3.0.CO;2-C

54. Shadidi KR, Aarvak T, Henriksen JE, Natvig JB, Thompson KM. The chemokines CCL5, CCL2 and CXCL12 play significant roles in the migration of Th1 cells into rheumatoid synovial tissue. Scand J Immunol. (2003) 57:192-8. doi: 10.1046/j.1365-3083.2003.01214.x

55. Haringman JJ, Smeets TJ, Reinders-Blankert P, Tak PP. Chemokine and chemokine receptor expression in paired peripheral blood mononuclear cells and synovial tissue of patients with rheumatoid arthritis, osteoarthritis, and reactive arthritis. Ann Rheum Dis. (2006) 65:294-300. doi: 10.1136/ard.2005.037176

56. Vergunst CE, Gerlag DM, Lopatinskaya L, Klareskog L, Smith MD, van den Bosch F, et al. Modulation of CCR2 in rheumatoid arthritis: a doubleblind, randomized, placebo-controlled clinical trial. Arthr Rheumat. (2008) 58:1931-9. doi: 10.1002/art.23591

57. van Kuijk AW, Vergunst CE, Gerlag DM, Bresnihan B, Gomez-Reino JJ, Rouzier R, et al. CCR5 blockade in rheumatoid arthritis: a randomised, double-blind, placebo-controlled clinical trial. Ann Rheum Dis. (2010) 69:2013-6. doi: 10.1136/ard.2010.131235

58. Lebre MC, Vergunst CE, Choi IY, Aarrass S, Oliveira AS, Wyant T, et al. Why CCR2 and CCR 5 blockade failed and why CCR1 blockade might still be effective in the treatment of rheumatoid arthritis. PLoS ONE (2011) 6:e21772. doi: 10.1371/journal.pone.0021772

59. Leong YA, Chen Y, Ong HS, Wu D, Man K, Deleage C, et al. CXCR5(+) follicular cytotoxic $\mathrm{T}$ cells control viral infection in B cell follicles. Nat Immunol. (2016) 17:1187-96. doi: 10.1038/ni.3543

60. Thaunat O, Field AC, Dai J, Louedec L, Patey N, Bloch MF, et al. Lymphoid neogenesis in chronic rejection: evidence for a local humoral alloimmune response. Proc Natl Acad Sci USA. (2005) 102:14723-8. doi: 10.1073/pnas.0507223102

61. Huibers MM, Gareau AJ, Beerthuijzen JM, Siera-de Koning E, van Kuik J, Kamburova EG, et al. Donor-specific antibodies are produced locally in ectopic lymphoid structures in cardiac allografts. Am J Transpl. (2017) 17:246-54. doi: 10.1111/ajt.13969

62. Deteix C, Attuil-Audenis V, Duthey A, Patey N, McGregor B, Dubois $\mathrm{V}$, et al. Intragraft Th17 infiltrate promotes lymphoid neogenesis and hastens clinical chronic rejection. J Immunol. (2010) 184:5344-51. doi: 10.4049/jimmunol.0902999

63. de Graav GN, Dieterich M, Hesselink DA, Boer K, Clahsen-van Groningen MC, Kraaijeveld R, et al. Follicular T helper cells and humoral reactivity in kidney transplant patients. Clin Exp Immunol. (2015) 180:329-40. doi: 10.1111/cei.12576

64. de Leur K, Clahsen-van Groningen MC, van den Bosch TPP, de Graav GN, Hesselink DA, Samsom JN, et al. Characterization of ectopic lymphoid structures in different types of acute renal allograft rejection. Clin Exp Immunol. (2018) 192:224-32. doi: 10.1111/cei.13099
65. Magliozzi R, Howell O, Vora A, Serafini B, Nicholas R, Puopolo M, et al. Meningeal B-cell follicles in secondary progressive multiple sclerosis associate with early onset of disease and severe cortical pathology. Brain (2007) 130:1089-104. doi: 10.1093/brain/awm038

66. Lovato L, Willis SN, Rodig SJ, Caron T, Almendinger SE, Howell OW, et al. Related B cell clones populate the meninges and parenchyma of patients with multiple sclerosis. Brain (2011) 134:534-41. doi: 10.1093/brain/awq350

67. Tzartos JS, Craner MJ, Friese MA, Jakobsen KB, Newcombe J, Esiri MM, et al. IL-21 and IL-21 receptor expression in lymphocytes and neurons in multiple sclerosis brain. Am J Pathol. (2011) 178:794-802. doi: 10.1016/j.ajpath.2010.10.043

68. Wan Y, Bai Y, Sun S, Qiu X, Zheng Y, Wang H, et al. Increased expression of transcription factor Bcl-6 in chronic rhinosinusitis with nasal polyps. Eur Arch Oto-rhino-Laryngol. (2016) 273:391-9. doi: 10.1007/s00405-015-3498-8

69. Xiao L, Jia L, Zhang Y, Yu S, Wu X, Yang B, et al. Human IL-21+IFNgamma+CD4+ T cells in nasal polyps are regulated by IL-12. Sci Rep. (2015) 5:12781. doi: 10.1038/srep12781

70. Zhang YN, Song J, Wang H, Wang H, Zeng M, Zhai GT, et al. Nasal IL$4^{+} \mathrm{CXCR}_{5}{ }^{+} \mathrm{CD}_{4}{ }^{+} \mathrm{T}$ follicular helper cell counts correlate with local $\mathrm{IgE}$ production in eosinophilic nasal polyps. J Allergy Clin Immunol. (2016) 137:462-73. doi: 10.1016/j.jaci.2015.07.025

71. Stone JH, Zen Y, Deshpande V. IgG4-related disease. N Eng J Med. (2012) 366:539-51. doi: 10.1056/NEJMra1104650

72. Maehara T, Moriyama M, Nakashima H, Miyake K, Hayashida JN, Tanaka A, et al. Interleukin-21 contributes to germinal centre formation and immunoglobulin G4 production in IgG4-related dacryoadenitis and sialoadenitis, so-called Mikulicz's disease. Ann Rheum Dis. (2012) 71:201119. doi: 10.1136/annrheumdis-2012-201477

73. Kamekura R, Takano K, Yamamoto M, Kawata K, Shigehara K, Jitsukawa $\mathrm{S}$, et al. Cutting edge: a critical role of lesional $\mathrm{T}$ follicular helper cells in the pathogenesis of IgG4-related disease. J Immunol. (2017) 199:2624-9. doi: 10.4049/jimmunol.1601507

74. Le Pottier L, Devauchelle V, Fautrel A, Daridon C, Saraux A, Youinou P, et al. Ectopic germinal centers are rare in Sjogren's syndrome salivary glands and do not exclude autoreactive B cells. J Immunol. (2009) 182:3540-7. doi: 10.4049/jimmunol.0803588

75. Odegard JM, Marks BR, DiPlacido LD, Poholek AC, Kono DH, Dong C, et al. ICOS-dependent extrafollicular helper T cells elicit IgG production via IL-21 in systemic autoimmunity. J Exp Med. (2008) 205:2873-86. doi: 10.1084/jem.20080840

76. Lee SK, Rigby RJ, Zotos D, Tsai LM, Kawamoto S, Marshall JL, et al. B cell priming for extrafollicular antibody responses requires Bcl-6 expression by T cells. J Exp Med. (2011) 208:1377-88. doi: 10.1084/jem.20102065

77. Poholek AC, Hansen K, Hernandez SG, Eto D, Chandele A, Weinstein JS, et al. In vivo regulation of $\mathrm{Bcl} 6$ and $\mathrm{T}$ follicular helper cell development. $J$ Immunol. (2010) 185:313-26. doi: 10.4049/jimmunol.0904023

78. Vu Van D, Beier KC, Pietzke LJ, Al Baz MS, Feist RK, Gurka S, et al. Local $\mathrm{T} / \mathrm{B}$ cooperation in inflamed tissues is supported by $\mathrm{T}$ follicular helper-like cells. Nat Commun. (2016) 7:10875. doi: 10.1038/ncomms10875

79. Coquet JM, Schuijs MJ, Smyth MJ, Deswarte K, Beyaert R, Braun H, et al. Interleukin-21-producing $\mathrm{CD} 4(+) \mathrm{T}$ cells promote type 2 immunity to house dust mites. Immunity (2015) 43:318-30. doi: 10.1016/j.immuni.2015. 07.015

80. Astorri E, Bombardieri M, Gabba S, Peakman M, Pozzilli P, Pitzalis C. Evolution of ectopic lymphoid neogenesis and in situ autoantibody production in autoimmune nonobese diabetic mice: cellular and molecular characterization of tertiary lymphoid structures in pancreatic islets. $J$ Immunol. (2010) 185:3359-68. doi: 10.4049/jimmunol.1001836

81. Papadakis KA, Prehn J, Nelson V, Cheng L, Binder SW, Ponath PD, et al. The role of thymus-expressed chemokine and its receptor CCR9 on lymphocytes in the regional specialization of the mucosal immune system. J Immunol. (2000) 165:5069-76. doi: 10.4049/jimmunol.165.9.5069

82. McGuire HM, Vogelzang A, Ma CS, Hughes WE, Silveira PA, Tangye SG, et al. A subset of interleukin-21+ chemokine receptor CCR9+ T helper cells target accessory organs of the digestive system in autoimmunity. Immunity (2011) 34:602-15. doi: 10.1016/j.immuni.2011.01.021

83. Blokland LM, Hillen MR, Kruize AA, Meller S, Homey B, Smithson GM, et al. Increased CCL25 and T helper cells expressing CCR9 in the salivary 
glands of patients with primary sjogren's syndrome: potential new axis in lymphoid neogenesis. Arthr Rheumatol. (2017) 69:2038-51. doi: 10.1002/art. 40182

84. Haskett S, Ding J, Zhang W, Thai A, Cullen P, Xu S, et al. Identification of novel CD4+ T cell subsets in the target tissue of sjogren's syndrome and their differential regulation by the lymphotoxin/LIGHT signaling axis. J Immunol. (2016) 197:3806-19. doi: 10.4049/jimmunol.1600407

85. Miyauchi K, Sugimoto-Ishige A, Harada Y, Adachi Y, Usami Y, Kaji T, et al. Protective neutralizing influenza antibody response in the absence of $\mathrm{T}$ follicular helper cells. Nat Immunol. (2016) 17:1447-58. doi: 10.1038/ni.3563

86. Carpio VH, Opata MM, Montanez ME, Banerjee PP, Dent AL, Stephens R. IFN-gamma and IL-21 double producing T cells are Bcl6-independent and survive into the memory phase in plasmodium chabaudi infection. PLoS ONE (2015) 10:e0144654. doi: 10.1371/journal.pone.0144654

87. Lu KT, Kanno Y, Cannons JL, Handon R, Bible P, Elkahloun AG, et al. Functional and epigenetic studies reveal multistep differentiation and plasticity of in vitro-generated and in vivo-derived follicular $\mathrm{T}$ helper cells. Immunity (2011) 35:622-32. doi: 10.1016/j.immuni.2011. 07.015

88. Nurieva RI, Chung Y, Hwang D, Yang XO, Kang HS, Ma L, et al. Generation of $\mathrm{T}$ follicular helper cells is mediated by interleukin-21 but independent of T helper 1, 2, or 17 cell lineages. Immunity (2008) 29:138-49. doi: 10.1016/j.immuni.2008.05.009

89. Suto A, Kashiwakuma D, Kagami S, Hirose K, Watanabe N, Yokote K, et al. Development and characterization of IL-21-producing CD4+ T cells. J Exp Med. (2008) 205:1369-79. doi: 10.1084/jem.20072057

90. Ma CS, Suryani S, Avery DT, Chan A, Nanan R, Santner-Nanan B, et al. Early commitment of naive human $\mathrm{CD} 4(+) \mathrm{T}$ cells to the $\mathrm{T}$ follicular helper (T(FH)) cell lineage is induced by IL-12. Immunol Cell Biol. (2009) 87:590-600. doi: 10.1038/icb.2009.64

91. Schmitt N, Liu Y, Bentebibel SE, Munagala I, Bourdery L, Venuprasad K, et al. The cytokine TGF-beta co-opts signaling via STAT3-STAT4 to promote the differentiation of human TFH cells. Nat Immunol. (2014) 15:856-65. doi: 10.1038/ni.2947

92. Nakayamada S, Kanno Y, Takahashi H, Jankovic D, Lu KT, Johnson TA, et al. Early Th1 cell differentiation is marked by a Tfh cell-like transition. Immunity (2011) 35:919-31. doi: 10.1016/j.immuni.2011.11.012

93. Hiramatsu Y, Suto A, Kashiwakuma D, Kanari H, Kagami S, Ikeda K, et al. c-Maf activates the promoter and enhancer of the IL-21 gene, and TGF-beta inhibits c-Maf-induced IL-21 production in CD4+ T cells. J Leukocyte Biol. (2010) 87:703-12. doi: 10.1189/jlb.0909639

94. Pot C, Jin H, Awasthi A, Liu SM, Lai CY, Madan R, et al. Cutting edge: IL-27 induces the transcription factor c-Maf, cytokine IL-21, and the costimulatory receptor ICOS that coordinately act together to promote differentiation of IL-10-producing Tr1 cells. J Immunol. (2009) 183:797-801. doi: 10.4049/jimmunol.0901233

95. Bauquet AT, Jin H, Paterson AM, Mitsdoerffer M, Ho IC, Sharpe AH, et al. The costimulatory molecule ICOS regulates the expression of c-Maf and IL-21 in the development of follicular T helper cells and TH-17 cells. Nat Immunol. (2009) 10:167-75. doi: 10.1038/ni.1690

96. Ansel KM, Ngo VN, Hyman PL, Luther SA, Forster R, Sedgwick JD, et al. A chemokine-driven positive feedback loop organizes lymphoid follicles. Nature (2000) 406:309-14. doi: 10.1038/35018581

97. Luther SA, Lopez T, Bai W, Hanahan D, Cyster JG. BLC expression in pancreatic islets causes B cell recruitment and lymphotoxindependent lymphoid neogenesis. Immunity (2000) 12:471-81. doi: 10.1016/S1074-7613(00)80199-5

98. Zheng B, Ozen Z, Zhang X, De Silva S, Marinova E, Guo L, et al. CXCL13 neutralization reduces the severity of collagen-induced arthritis. Arthr Rheum. (2005) 52:620-6. doi: 10.1002/art.20768

99. Bracke KR, Verhamme FM, Seys LJ, Bantsimba-Malanda C, Cunoosamy DM, Herbst R, et al. Role of CXCL13 in cigarette smoke-induced lymphoid follicle formation and chronic obstructive pulmonary disease. Am J Respir Crit Care Med. (2013) 188:343-55. doi: 10.1164/rccm.2012112055OC

100. Brodfuehrer J, Rankin A, Edmonds J, Keegan S, Andreyeva T, LawrenceHenderson R, et al. Quantitative analysis of target coverage and germinal center response by a CXCL13 neutralizing antibody in a Tdependent mouse immunization model. Pharm Res. (2014) 31:635-48. doi: 10.1007/s11095-013-1185-2

101. Yamamoto K, Nishiumi S, Yang L, Klimatcheva E, Pandina T, Takahashi S, et al. Anti-CXCL13 antibody can inhibit the formation of gastric lymphoid follicles induced by Helicobacter infection. Mucos Immunol. (2014) 7:124454. doi: 10.1038/mi.2014.14

102. Wu X, Guo J, Ding R, Lv B, Bi L. CXCL13 blockade attenuates lupus nephritis of MRL/lpr mice. Acta Histochem. (2015) 117:732-7. doi: 10.1016/j.acthis.2015.09.001

103. Sharma A, Kiripolsky J, Klimatcheva E, Howell A, Fereidouni F, Levenson R, et al. Early BAFF receptor blockade mitigates murine Sjogren's syndrome: concomitant targeting of CXCL13 and the BAFF receptor prevents salivary hypofunction. Clin Immunol. (2016) 164:85-94. doi: 10.1016/j.clim.2016.01.015

104. Yu H, Shahsafaei A, Dorfman DM. Germinal-center T-helper-cell markers PD-1 and CXCL13 are both expressed by neoplastic cells in angioimmunoblastic T-cell lymphoma. Am J Clin Pathol. (2009) 131:33-41. doi: 10.1309/AJCP62WRKERPXDRT

105. Gu-Trantien C, Migliori E, Buisseret L, de Wind A, Brohee S, Garaud $S$, et al. CXCL13-producing TFH cells link immune suppression and adaptive memory in human breast cancer. JCI Insight (2017) 2:e91487. doi: 10.1172 /jci.insight.91487

106. Havenar-Daughton C, Lindqvist M, Heit A, Wu JE, Reiss SM, Kendric K, et al. CXCL13 is a plasma biomarker of germinal center activity. Proc Natl Acad Sci USA. (2016) 113:2702-7. doi: 10.1073/pnas.1520112113

107. Manzo A, Vitolo B, Humby F, Caporali R, Jarrossay D, Dell'accio F, et al. Mature antigen-experienced $\mathrm{T}$ helper cells synthesize and secrete the B cell chemoattractant CXCL13 in the inflammatory environment of the rheumatoid joint. Arthr Rheumat. (2008) 58:3377-87. doi: 10.1002/art. 23966

108. Kobayashi S, Murata K, Shibuya H, Morita M, Ishikawa M, Furu M, et al. A distinct human CD4+ T cell subset that secretes CXCL13 in rheumatoid synovium. Arthr Rheumat. (2013) 65:3063-72. doi: 10.1002/art.38173

109. Stephenson W, Donlin LT, Butler A, Rozo C, Bracken B, Rashidfarrokhi A, et al. Single-cell RNA-seq of rheumatoid arthritis synovial tissue using low-cost microfluidic instrumentation. Nat Commun. (2018) 9:791. doi: 10.1038/s41467-017-02659-x

110. Dennis G Jr., Holweg CT, Kummerfeld SK, Choy DF, Setiadi AF, Hackney JA, et al. Synovial phenotypes in rheumatoid arthritis correlate with response to biologic therapeutics. Arthr Res Ther. (2014) 16:R90. doi: 10.1186/ar4555

111. Bugatti S, Manzo A, Vitolo B, Benaglio F, Binda E, Scarabelli M, Humby F, et al. High expression levels of the B cell chemoattractant CXCL13 in rheumatoid synovium are a marker of severe disease. Rheumatology (2014) 53:1886-95. doi: 10.1093/rheumatology/keu163

112. Ngo VN, Korner H, Gunn MD, Schmidt KN, Riminton DS, Cooper MD, et al. Lymphotoxin alpha/beta and tumor necrosis factor are required for stromal cell expression of homing chemokines in B and $\mathrm{T}$ cell areas of the spleen. $J$ Exp Med. (1999) 189:403-12. doi: 10.1084/jem.189.2.403

113. Rangel-Moreno J, Carragher DM, de la Luz Garcia-Hernandez M, Hwang JY, Kusser K, Hartson L, et al. The development of inducible bronchusassociated lymphoid tissue depends on IL-17. Nat Immunol. (2011) 12:63946. doi: 10.1038/ni.2053

114. Zheng C, Zheng L, Yoo JK, Guo H, Zhang Y, Guo X, et al. Landscape of infiltrating $\mathrm{T}$ cells in liver cancer revealed by single-cell sequencing. Cell (2017) 169:1342-56 e16. doi: 10.1016/j.cell.2017.05.035

115. Chen MM, Xiao X, Lao XM, Wei Y, Liu RX, Zeng QH, et al. Polarization of tissue-resident TFH-like cells in human hepatoma bridges innate monocyte inflammation and M2b macrophage polarization. Cancer Discov. (2016) 6:1182-95. doi: 10.1158/2159-8290.CD-16-0329

116. Gu-Trantien C, Loi S, Garaud S, Equeter C, Libin M, de Wind A, et al. $\mathrm{CD} 4(+)$ follicular helper $\mathrm{T}$ cell infiltration predicts breast cancer survival. J Clin Invest. (2013) 123:2873-92. doi: 10.1172/JCI67428

117. Workel HH, Lubbers JM, Arnold R, van der Vlies P, de Lange K, Bosse T, van Gool I, et al. TGF- $\beta$ induced CXCL13 in CD8+ T cells is associated with tertiary lymphoid structures in cancer. bioRxiv [Preprint] (2018) doi: $10.1101 / 303834$ 
118. Bindea G, Mlecnik B, Tosolini M, Kirilovsky A, Waldner M, Obenauf AC, et al. Spatiotemporal dynamics of intratumoral immune cells reveal the immune landscape in human cancer. Immunity (2013) 39:782-95. doi: 10.1016/j.immuni.2013.10.003

119. Wei SC, Levine JH, Cogdill AP, Zhao Y, Anang NAS, Andrews $\mathrm{MC}$, et al. Distinct cellular mechanisms underlie anti-CTLA-4 and anti-PD-1 checkpoint blockade. Cell (2017) 170:1120-33 el7. doi: 10.1016/j.cell.2017.07.024

120. Zappasodi R, Budhu S, Hellmann MD, Postow MA, Senbabaoglu Y, Manne $\mathrm{S}$, et al. Non-conventional inhibitory CD4(+)Foxp3(-)PD-1(hi) T cells as a biomarker of immune checkpoint blockade activity. Cancer Cell (2018) 33:1017-32 e7.

121. Kobayashi S, Watanabe T, Suzuki R, Furu M, Ito H, Ito J, et al. TGF-beta induces the differentiation of human CXCL13-producing CD4(+) T cells. Eur J Immunol. (2016) 46:360-71. doi: 10.1002/eji.201546043

122. Locci M, Wu JE, Arumemi F, Mikulski Z, Dahlberg C, Miller AT, et al. Activin A programs the differentiation of human TFH cells. Nat Immunol. (2016) 17:976-84. doi: 10.1038/ni.3494

123. Takagi R, Higashi T, Hashimoto K, Nakano K, Mizuno Y, Okazaki Y, et al. B cell chemoattractant CXCL13 is preferentially expressed by human Th17 cell clones. J Immunol. (2008) 181:186-9. doi: 10.4049/jimmunol.181.1.186

124. Kimura N, Yamagiwa S, Sugano T, Setsu T, Tominaga K, Kamimura H, et al. Possible involvement of chemokine $\mathrm{C}-\mathrm{C}$ receptor $7(-)$ programmed cell death-1(+) follicular helper T-cell subset in the pathogenesis of autoimmune hepatitis. J Gastroenterol Hepatol. (2018) 33:298-306. doi: 10.1111/jgh.13844

125. Taylor DK, Mittereder N, Kuta E, Delaney T, Burwell T, Dacosta K, et al. T follicular helper-like cells contribute to skin fibrosis. Sci Trans Med. (2018) 10. doi: 10.1126/scitranslmed.aaf5307

126. Wang L, Sun Y, Zhang Z, Jia Y, Zou Z, Ding J, et al. CXCR5+ $\mathrm{CD} 4+\mathrm{T}$ follicular helper cells participate in the pathogenesis of primary biliary cirrhosis. Hepatology (2015) 61:627-38. doi: 10.1002/hep. 27306

127. Zhu C, Ma J, Liu Y, Tong J, Tian J, Chen J, et al. Increased frequency of follicular helper $\mathrm{T}$ cells in patients with autoimmune thyroid disease. J Clin Endocrinol Metab. (2012) 97:943-50. doi: 10.1210/jc. 2011-2003

Conflict of Interest Statement: DR is an inventor in a patent submitted on Tph cells.

Copyright (c) 2018 Rao. This is an open-access article distributed under the terms of the Creative Commons Attribution License (CC BY). The use, distribution or reproduction in other forums is permitted, provided the original author(s) and the copyright owner(s) are credited and that the original publication in this journal is cited, in accordance with accepted academic practice. No use, distribution or reproduction is permitted which does not comply with these terms. 